Please do not remove this page

RMIT

UNIVERSITY

\title{
Self expression versus the environment: Attitudes in conflict
}

Parker, Lukas; Aleti, Torgeir; Brennan, Linda-Marie; Duong Trong, Hue; Nguyen Hong Hai, Dang https://researchrepository.rmit.edu.au/esploro/outputs/9921859426201341/filesAndLinks?institution=61 RMIT_INST\&index=null

Parker, L., Aleti, T., Brennan, L.-M., Duong Trong, H., \& Nguyen Hong Hai, D. (2014). Self expression versus the environment: Attitudes in conflict. Young Consumers, 15(2), 138-152.

https://doi.org/10.1108/YC-06-2013-00383

Document Version: Accepted Manuscript

Published Version: https://doi.org/10.1108/YC-06-2013-00383

Repository homepage: https://researchrepository.rmit.edu.au

(c) Emerald Group Publishing Limited

Downloaded On 2023/04/26 12:15:46 +1000 
Thank you for downloading this document from the RMIT Research Repository.

The RMIT Research Repository is an open access database showcasing the research outputs of RMIT University researchers.

RMIT Research Repository: http://researchbank.rmit.edu.au/

\section{Citatioon:}

Parker, L, Aleti, T, Brennan, L, Duong Trong, H and Nguyen Hong Hai, D 2014, 'Self expression versus the environment: Attitudes in conflict', Young Consumers, vol. 15, no. 2, pp. 138-152.

See this record in the RMIT Research Repository at:

https://researchbank.rmit.edu.au/view/rmit:24609

Version: Accepted Manuscript

Copyright Statement: (c) Emerald Group Publishing Limited

Link to Published Version:

http://dx.doi.org/10.1108/YC-06-2013-00383

\section{PLEASE DO NOT REMOVE THIS PAGE}




\title{
Self Expression versus the Environment: Values in conflict
}

\author{
Abstract \\ Purpose \\ This paper presents the findings of a survey into attitudes towards the environment and the \\ pro-environmental behaviours of young adults in Vietnam.

\section{Design/methodology/approach}

An online survey was administered to university students in Vietnam's two most populous cities, Ha Noi and Ho Chi Minh City in Vietnam $(N=391)$.

\section{Findings}

The results suggest that environmental considerations are not taken into account in young Vietnamese adults' purchase intentions. This is more evident in expressive purchases, but also in to some degree in utilitarian purchases.

\section{Practical Implications}

For the marketers of environmentally friendly products this represents at least two key challenges: first, to try to shift the attitudes of young adult consumers towards thinking of environmental friendliness as an attractive characteristic and status-filled activity for potential expressive purchases. Second, making environmentally friendly alternatives of expressive goods more visible and more widely available in Vietnam.

\section{Social Implications}

Non government organizations and governments seeking to protect the environment need to consider this unique dynamic in social marketing campaigns in order to increase the desirability of pro-environmental product choices and other pro-environmental behaviours.

\section{Originality/value}

This is an author's pre-published copy of the paper Parker, L., Brennan, L., Watne, T. A., Duong, H. T., Nguyen, D. (2014). Self Expression versus the Environment: Attitudes in conflict. Young Consumers, 15(2), 138-152. 
This paper examines pro-environmental behaviours and intentions of young adults in Vietnam for the first time. The paper establishes that self-expression is more important than the environment, and it is also evident that these young consumers are still vulnerable to perceived social pressure when it comes to expressing themselves.

Keywords: New Ecological Paradigm, pro-environmental behaviour, consumer behaviour, young consumers, Asian values

\section{Category: Research paper}

This is an author's pre-published copy of the paper Parker, L., Brennan, L., Watne, T. A., Duong, H. T., Nguyen, D. (2014). Self Expression versus the Environment: Attitudes in conflict. Young Consumers, 15(2), 138-152. 


\section{Self Expression versus the Environment: Values in conflict}

\section{Introduction}

Ha Noi and Ho Chi Minh City are the two most populous cities in Vietnam and are facing environmental problems typical to that of most major cities in developing countries in Southeast Asia, including airborne pollution, water contamination and treatment, and problems associated with hard waste management, recycling and disposal. Some of these concerns have manifested themselves in traffic congestion, water-borne disease and rolling scheduled electricity supply cuts (Dung, 2011; Thanh Niên, 2011; VietNamNet, 2009). In addition to infrastructure and developmental pressures, there is the pressure of a rapidly growing middle class (General Statistics Office, 2009).

The newly arising middle class in Vietnam is both large and relatively wealthy (Penz \& Kirchler, 2011). Middle classes are often characterized by their consumption patterns (de Mooij \& Hofstede, 2002; Hanser, 2010). The middle classes often aspire to the products and services that endow them with social status, prestige and an appearance of 'taste' (Hughes \& Woldekidan, 1994; Singh, 2005). As such, expressive purchases are paramount (Holt, 2004; Nayeem, 2011; Ogden, Ogden, \& Schau, 2004). Kim (2011) found that this need for selfexpression in purchasing could be taken to extremes in the Korean cultural context, with some young people financially ruining themselves in the search for the status that comes with conspicuous consumption. Kim (2011, p. iv) linked this to Asian cultural values such as collectivism and love of authenticity, combined with an 'indiscreet' adoption of Western consumption values. The widespread adoption of Western consumerism is a serious concern throughout Asia, including Vietnam, primarily because of the potential impact on the environment (Bardhan, 2006; Sheth, 2011; Sheth, Sethia, \& Srinivas, 2011).

This is an author's pre-published copy of the paper Parker, L., Brennan, L., Watne, T. A., Duong, H. T., Nguyen, D. (2014). Self Expression versus the Environment: Attitudes in conflict. Young Consumers, 15(2), 138-152. 


\section{Environmental Attitudes and Behaviour Research}

Environmental awareness and active environmentally responsible behaviour is a relatively new phenomenon in Vietnam. Studies as far back as 2002 reported a lack of environmental awareness amongst Vietnamese people (Nguyen \& Amin, 2002). In more recent times, new items about environmental issues in the industrial context (Hoang Loc \& Duc Tuyen, 2012; Thu Hang, 2012), have profiled cases of large multinational businesses acting environmentally recklessly (VietNamNet, 2009). These news items have served to generate awareness and anger amongst the general population, and in some cases have led to the tightening up of environmental protection laws and prosecution (Thanh Niên, 2011). However, this does not appear to have led to any identified behaviour change with regard to pro-environmental activities. In a Vietnamese context, the actions that an individual can take to protect the environment are not well-defined or described. As yet, we have found no evidence of social marketing campaigns advocating individual behaviour change in the Vietnamese context.

Evidence elsewhere suggests that a higher level of concern for the environment will lead to greater degrees of effort with regards to conservation (Cleveland, Kalamas, \& Laroche, 2012; Roberts \& Bacon, 1997). However, Schroeder (2011) identifies a belief, held by many consumers, that science and technology can resolve what individuals cannot. Further, Xiao's (2011) research found that a belief in the efficacy of science and technology in resolving environmental problems was causally linked to attitudes and concern for the environment. Thus, the individual's acceptance of a need for independent action with regard to protecting the environment may not be as great if there is a sense that 'someone else' can,

This is an author's pre-published copy of the paper Parker, L., Brennan, L., Watne, T. A., Duong, H. T., Nguyen, D. (2014). Self Expression versus the Environment: Attitudes in conflict. Young Consumers, 15(2), 138-152. 
and will, take care of the problem (Cin, 2012). In these cases, the individual does not accept the responsibility and therefore does not act in relation to the issue. Explanatory theories for where this occurs are as diverse as prospect theory (Kahneman \& Tversky, 1984; Tversky \& Kahneman, 1981), diffusion of responsibility (Mynatt \& Sherman, 1975; Wallach, Kogan, \& Bem, 1964) and self-protection motivation (Floyd, Prentice-Dunn, \& Rogers, 2000; Fritsche \& Hafner, 2011). However, regardless of the theory, the practical consequence is that individuals do not act if they do not feel the need to. When it comes to environmental issues, individual responsibility may be more diffused in domains with lower levels of understanding of the capabilities of technology at the grass roots level, such as that which exists in some areas of Vietnam. That is, a level of knowledge about the environment is a necessary precursor to action. Furthermore, as pointed out by Kurz and Baudains (2012), the success of any environmental effort is inseparably linked to the way the human members of the ecosystem think and behave. Whether consumers in Vietnam personally take action in relation to pro-environmental consumption decisions has so far not been investigated. Further, while there is evidence in other contexts such as that of Perera (2013), this has not been extended to the developing country context.

In addition to individual motivations and actions, is the broader social context of such behaviours. Behavioural aspects of consumption are culturally bound (Blodgett, Bakir, \& Rose, 2008; de Mooij \& Hofstede, 2002; Soares, Farhangmehr, \& Shoham, 2007). However, most marketing theories rely on what can be referred to as a 'Western' perspective of the individual as an independent, autonomous identity, free to make decision based on purely personal desire and affiliations (Roll, 2006). This approach to human behaviour and behavioural intent is reflected in many well-established Western theories used in marketing. For example, Maslow’s (1943) Hierarchy of Needs is to be found in most basic marketing and consumer behaviour textbooks. An alternative to Maslow's theory was proposed by

This is an author's pre-published copy of the paper Parker, L., Brennan, L., Watne, T. A., Duong, H. T., Nguyen, D. (2014). Self Expression versus the Environment: Attitudes in conflict. Young Consumers, 15(2), 138-152. 
Schütte and Ciarlante (1998) and was termed an Asian hierarchy of needs. As opposed to Maslow's hierarchy, the needs on the top of the Asian pyramid relate to social needs such as status and admiration rather than self esteem and self actualization. This theory indicates greater importance of the collective in Asian societies.

Support for Schütte and Ciarlante’s (1998) contention that status is the highestranking need in the Asian hierarchy can be seen in the geographic breakdown of the $\$ 35$ billion global luxury goods market. Fully 20 percent of industry sales are generated in Japan alone, with another 22 percent of sales occurring in the rest of the Asia-Pacific region. Nearly half of all sales revenues of Italy’s Gucci Group are generated in Asia (Keegan \& Green, 2010). Thus, in a Vietnamese context, expressing status and admiration may be more important than concerns for the environment in expressive product categories such as apparel.

In these circumstances, the challenge becomes: how to get individuals to behave in an environmentally significant (and conscious) way? Stern (2000) proposed four distinct environmentally significant behaviour categories: environmental activism, non-activist behaviours in the public sphere, private sphere environmentalism and other environmentally significant behaviours. This study focuses on private-sphere environmentalism because, unlike other public-sphere environmentalism activities, these individual behaviours have direct environmental consequences (Osbaldiston \& Sheldon, 2003; Stern, 2000) and are most relevant to consumer decision making.

\section{Environmental Concern and Consumer Behaviour}

A large body of research into environmental attitudes or concerns has emerged recently (for a brief selection see Amburgey \& Thoman, 2011; Corral-Verdugo et al., 2008; Deng, Walker, \& Swinnerton, 2006; Johnson, Bowker, \& Cordell, 2004). A core concept

This is an author's pre-published copy of the paper Parker, L., Brennan, L., Watne, T. A., Duong, H. T., Nguyen, D. (2014). Self Expression versus the Environment: Attitudes in conflict. Young Consumers, 15(2), 138-152. 
within this domain is that of attitudes leading to intentions and therefore behaviours. That is, behaviours are planned or reasoned outcomes of intentions and prior attitudes. These are largely based on the Theory of Planned Behaviour (Ajzen, 1991) and its earlier variant, the Theory of Reasoned Action (Ajzen \& Fishbein, 1980).

A first step in these models is that of determining prevailing attitudes. This is instrumental in determining whether or not attitudes and intentions may lead to behaviours in the environmental domain. A common method of measuring attitudes towards the environment is that of the New Environmental Paradigm, first used by Dunlap and Van Liere (1978), and its later hybrid, the New Ecological Paradigm (NEP) (Dunlap et al., 2000). Surveys using their scales have been undertaken in hundreds of studies and many countries (Hawcroft \& Milfont, 2010), including other developing countries in the region, like China (see for example, Chung \& Poon, 1999, 2001), India (Schultz et al., 2005), and Indonesia (Watson \& Halse, 2005).

In addition to attitudes, values and social norms need to be understood (Schwartz, 1992; Schwartz et al., 2001; Thogersen \& Ölander, 2003). Thogersen (2006) and Thogersen and Ölander (2003) found limited evidence that environmentally friendly consumption patterns spread through social groups; however, others have found that group norms are powerful motivators for specific behaviours (Cialdini, Reno, \& Kallgren, 1990; Kallgren, Reno, \& Cialdini, 2000; Lapinski \& Rimal, 2005; Schultz et al., 2007). Furthermore, while norms may be the impetus for action, according to Stern, Dietz and Kalhof (1993), the value orientation of the individual is potentially more important with regards to propensity to pay more or perception of the severity of the threat to their environment. There are the added dimensions of perceived behavioural control (Cleveland et al., 2012; Munro et al., 2007) or self-efficacy (Rosentrater et al., 2012) and sense of responsibility (Cheng \& Monroe, 2012). In addition, there are deeper cultural values that have been demonstrated to be influential, 
especially in relation to the NEP (Johnson, et al., 2004; Vikan, Camino, Biaggio, \& Nordvik, 2007).

However, while the above argument establishes that people are concerned about the environment, what action they take in relation to these concerns is less clear. Moreover, given that social norms regarding consumption can be destructive in some cases, (Kim, 2011), it is important to understand the link between self-expressive purchases and environmental concerns. In spite of this, knowledge about whether or not young people in developing countries are willing to limit their consumption of self-expressive products as a result of their stated concerns is limited. Some limited research in other countries in the region has been conducted (Ngai \& Cho, 2012; Lee et al, 2013). Further, research demonstrates that young people are often more environmentally conscious than their older counterparts (Nooney, Woodrum, Hoban, \& Clifford, 2003) and that they can be influential regarding environmental behaviours in the household (Watne \& Brennan, 2012). Thus, they hold a promise for the future if they can be persuaded to consume responsibly (Cini, Leone, \& Passafaro, 2012).

Individual human beings must make the requisite changes to their own behaviours in terms of (say) consumption of energy, water, products and waste in order to decrease demand for environmentally costly products and services. This paper examines the relationship between attitudes towards the environment and environmentally friendly intentions regarding consumption in Vietnam. The fundamental premise is that environmentally responsible behaviour is an outcome of considered action on behalf of an individual. Expressive products are status 'filled' and as such make public representations about the person in relation to their potentially hidden beliefs about themselves. As a result the social risk associated with purchase potentially outweighs concern for the environment. Thus, we aimed to establish if

This is an author's pre-published copy of the paper Parker, L., Brennan, L., Watne, T. A., Duong, H. T., Nguyen, D. (2014). Self Expression versus the Environment: Attitudes in conflict. Young Consumers, 15(2), 138-152. 
pro-environmental beliefs are a driver of consumption intentions when it comes to selfexpressive products.

Figure 1 contains a pictorial representation of the conceptual framework that was used to develop the research questions and hypotheses for the empirical study.

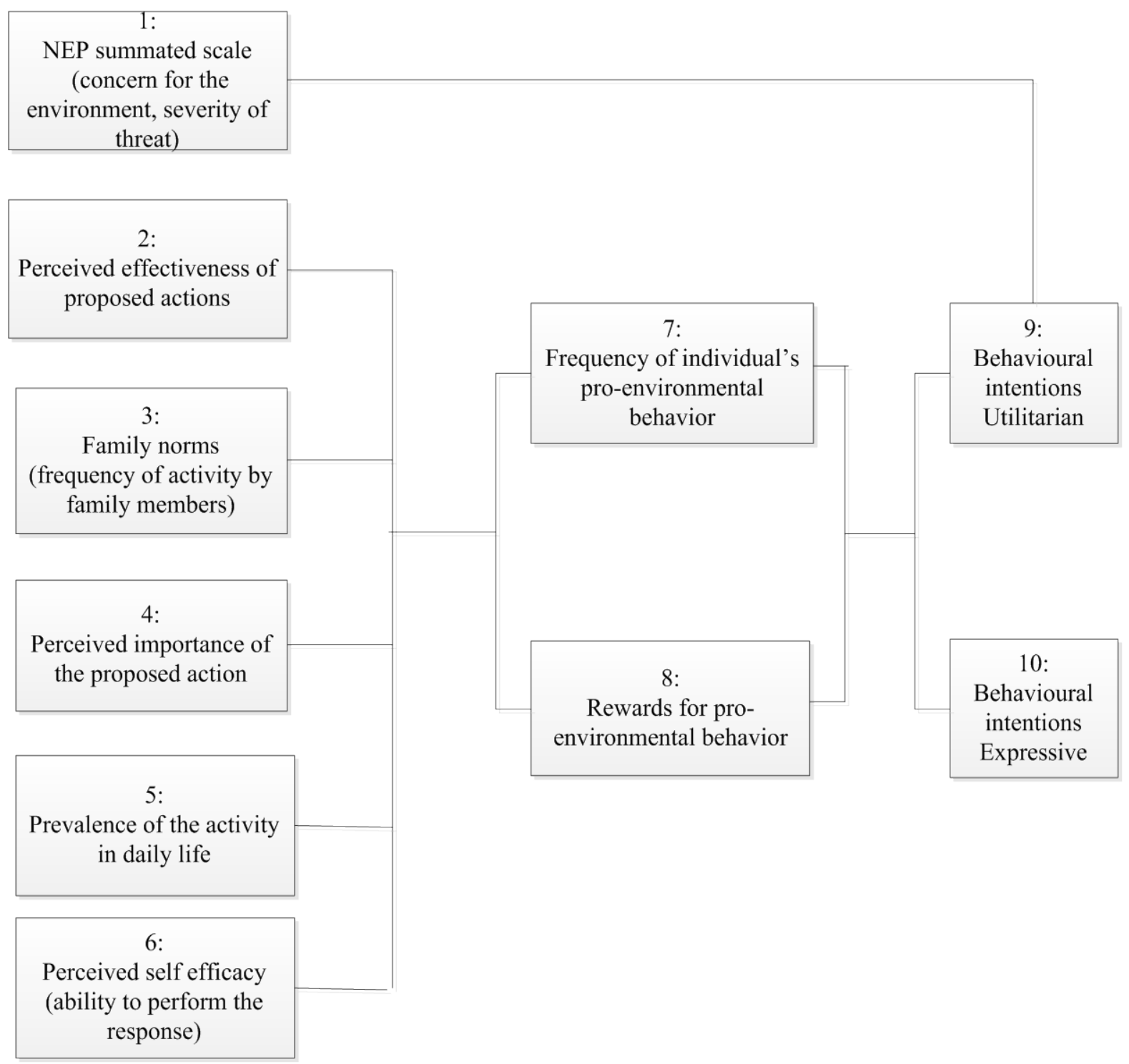

Figure 1. Conceptual model of young adults’ behavioral intentions

This is an author's pre-published copy of the paper Parker, L., Brennan, L., Watne, T. A., Duong, H. T., Nguyen, D. (2014). Self Expression versus the Environment: Attitudes in conflict. Young Consumers, 15(2), 138-152. 


\section{Research Questions and Hypotheses}

First of all, this project investigated young Vietnamese' attitude towards the environment. As mentioned, the NEP is commonly used to measure this orientation. Typical items in the NEP are "We are approaching the limit of the number of people the earth can support" and "When humans interfere with nature it often produces disastrous consequences”. In order to ascertain if attitudes towards the environment would moderate stated intentions regarding behaviours and product categories, the following hypothesis was established:

H1a: Young adults will adjust their stated intentions regarding purchases in accordance to their stated attitudes: positive attitudes towards the environment will lead to an increase in consideration for the environment in their purchase intentions.

The importance of considering the environment in a broad range of product categories was investigated. Categories were further classified into utilitarian (e.g. food at home, paper for printing, motorbike) and expressive (e.g. clothes, books, laptop, mobile phone, laptop) purchases. The proposition is that young Vietnamese may be less likely to consider the environment with regards to expressive purchases because of the cultural importance placed on status symbols. Therefore, following two hypotheses were suggested:

H1b: Positive attitudes towards the environment will lead to an increase in consideration for the environment in the young adults' purchase intentions in terms of expressive products.

This is an author's pre-published copy of the paper Parker, L., Brennan, L., Watne, T. A., Duong, H. T., Nguyen, D. (2014). Self Expression versus the Environment: Attitudes in conflict. Young Consumers, 15(2), 138-152. 
H1c: Positive attitudes towards the environment will lead to an increase in consideration for the environment in the young adults' purchase intentions in terms of utilitarian products.

In addition to these hypotheses, those factors that had been previously identified (in other studies cited earlier in this paper) as pertaining to environmental attitudes and behaviours lead to the following hypothesis and sub-hypotheses.

H2a: Young adults’ perceived self-efficacy in relation to their own pro-environmental activities is not influenced by their attitudes towards the environment H2b: Young adults' perceived importance of pro-environmental activities is not influenced by their attitudes towards the environment

H2c: Young adults' sense of personal reward related to participating in proenvironmental activities is not influenced by their attitudes towards the environment H2d: Young adults' frequency of participating in pro-environmental activities is not influenced by their attitudes towards the environment

H2e: Young adults' beliefs about how often their significant others participate in proenvironmental behaviours are not influenced by their attitudes towards the environment

This second set of hypotheses was used as a form of benchmark for the first set of hypotheses in terms of variance and relative means. Thus, they were used as a baseline measure for all variables.

This is an author's pre-published copy of the paper Parker, L., Brennan, L., Watne, T. A., Duong, H. T., Nguyen, D. (2014). Self Expression versus the Environment: Attitudes in conflict. Young Consumers, 15(2), 138-152. 


\section{Methodology}

Data were collected by online survey in English from upwardly mobile Vietnamese students studying at an English speaking university in Vietnam. An online survey was developed based on focus group outcomes and existing validated scales drawn from the literature. Online surveys are a means to reach a wider audience in Vietnam, as most middle class Vietnamese have ready access to and are active users of the Internet (General Statistics Office, 2009). They also respond relatively readily to surveys of this kind. Sax et al., (2008) found that response rates and bias by standard mail or email request were not essentially different.

The survey instrument was designed to investigate the level of agreement with a set of statements regarding:

1) Perceived severity of the threat and concern about the environment using the NEP scale of Dunlap and Van Liere (2000).

2) Perceived effectiveness of a series of proposed pro-environmental activities in responding to environmental threat (Fritsch \& Hafner, 2011).

3) How usual the behaviour was within the immediate social circle (social norms) (Cordano et al., 2011; Nordlund \& Garvill, 2002; Thogersen, 2006; Widegren, 1998). These descriptive norms were assessed using a frequency of pro-environmental activity by family members scale. These are called family norms in the conceptual framework.

4) The importance undertaking specific pro-environmental behaviours was ascertained using an agree-to-disagree scale (7-point). This set of questions were designed to ascertain 'importance’ rather than ‘severity’ perceptions

This is an author's pre-published copy of the paper Parker, L., Brennan, L., Watne, T. A., Duong, H. T., Nguyen, D. (2014). Self Expression versus the Environment: Attitudes in conflict. Young Consumers, 15(2), 138-152. 
5) Perceived level of control over whether or not that behaviour could be undertaken (self-efficacy) (Donovan \& Henley, 2003; Homburg \& Stolberg, 2006; Zavestoski, 2002).

6) Reported frequency of environmentally friendly behaviours by the individual (Bonnes, Passafaro, \& Carrus, 2011; Nisbet, Zelenski, \& Murphy, 2009).

7) Perceived rewards associated with pro-environmental behaviour (for example, giving up 'something' in order to be 'green’ is a negatively framed reward) (Hallin, 1995).

Reliability of the scales and sub-scales was tested in terms of internal consistencies with Cronbach’s Alpha (Cronbach, 1951). The Cronbach’s Alpha values for all items ranged between .68 and .91 which is considered as being reliable (Churchill \& Iacobucci, 2005). Using the process suggested by De Vellis (2003) the sub-scales were subsequently combined to generate a single item or index variable.

Of the 391 responses to the survey 60.4 percent of the respondents were female and 97.7 percent were between the ages of 18 and 25. Eighty-six point five percent of the respondents were living in Ho Chi Minh City, with the remainder from Ha Noi. While there are differences in cultural background between these regions the results demonstrated sufficient homogeneity to combine into a single data set for analysis.

\section{Results}

Table 1 shows the summary statistics for which all the data are available. The significance of the differences is indicated in the final column. The relationship between attitudes towards the environment as expressed in the NEP and the other variables is

This is an author's pre-published copy of the paper Parker, L., Brennan, L., Watne, T. A., Duong, H. T., Nguyen, D. (2014). Self Expression versus the Environment: Attitudes in conflict. Young Consumers, 15(2), 138-152. 
significant at the 0.10 level in two cases; and is significant at the 0.05 level for the other variables.

Table 1. Summary Statistics for Measures

\begin{tabular}{lccccccc}
\hline & & & & & Std. & & \\
& $N$ & Min & Max & Mean & Dev & Var & Sig. \\
\hline 1 NEP Summated scale & 391 & 1 & 6 & 3.1 & 0.68 & 0.46 & \\
2 Effectiveness of action & 391 & 1 & 6 & 2.7 & 0.89 & 0.79 & 0.00 \\
3 Family norms & 391 & 1 & 6 & 3.7 & 0.98 & 0.95 & 0.00 \\
4 Importance of action & 391 & 1 & 6 & 2.4 & 0.89 & 0.80 & 0.08 \\
5 Self efficacy and control & 391 & 1 & 7 & 3.3 & 1.05 & 1.11 & 0.00 \\
6 Frequency of indiv action & 391 & 1 & 6 & 3.4 & 0.93 & 0.87 & 0.01 \\
7 Reward for behaviour & 391 & 1 & 7 & 2.4 & 0.96 & 0.93 & 0.04 \\
8 BI Utilitarian purchases & 391 & 1 & 7 & 3.3 & 1.50 & 2.24 & 0.01 \\
9 BI Expressive purchases & 391 & 1 & 7 & 4.2 & 1.49 & 2.23 & 0.08 \\
\hline Valid $N$ (listwise) & 391 & & & & & & \\
\hline
\end{tabular}

As a result of these significant differences, the Pearson Product-moment coefficients of correlation were calculated for all nine variables in the model. The outcome of this analysis is shown in Table 2.

Table 2. Correlations Amongst Independent Variables

\begin{tabular}{|c|c|c|c|c|c|c|c|c|c|}
\hline & 1 & 2 & 3 & 4 & 5 & 6 & 7 & 8 & 9 \\
\hline $\begin{array}{l}1 \text { NEP Summated } \\
\text { scale }\end{array}$ & 1 & & & & & & & & \\
\hline $\begin{array}{l}2 \text { Effectiveness of } \\
\text { action }\end{array}$ & $0.14 *$ & 1 & & & & & & & \\
\hline 3 Family norms & $0.21^{* *}$ & $0.11^{*}$ & 1 & & & & & & \\
\hline $\begin{array}{l}4 \text { Importance of action } \\
\text { for the environment }\end{array}$ & $0.11 *$ & $0.50 * *$ & $0.22 * *$ & 1 & & & & & \\
\hline $\begin{array}{l}5 \text { Self efficacy and } \\
\text { control }\end{array}$ & $0.13^{*}$ & $0.21^{* *}$ & $0.50 * *$ & $0.39 * *$ & 1 & & & & \\
\hline $\begin{array}{l}6 \text { Frequency of indiv } \\
\text { action }\end{array}$ & $0.10^{*}$ & 0.08 & $0.37 * *$ & $0.15^{* *}$ & $0.44 * *$ & 1 & & & \\
\hline $\begin{array}{l}7 \text { Reward for } \\
\text { behaviour }\end{array}$ & 0.09 & $0.26^{* *}$ & $0.23 * *$ & $0.41 * *$ & $0.34 * *$ & $0.24^{* *}$ & 1 & & \\
\hline 8 Utilitarian purchases & $0.16^{* *}$ & $0.10 *$ & $0.14^{* *}$ & $0.16^{* *}$ & $0.21 * *$ & $0.31^{* *}$ & $0.20 * *$ & 1 & \\
\hline 9 Expressive purchases & $0.12 *$ & 0.06 & $0.22 * *$ & $0.22 * *$ & $0.29 * *$ & $0.33 * *$ & $0.19 * *$ & $0.61 * *$ & 1 \\
\hline
\end{tabular}

**Correlation is significant at the .001 level (2-tailed)

*Correlation is significant at the 0.05 level (2-tailed).

This is an author's pre-published copy of the paper Parker, L., Brennan, L., Watne, T. A., Duong, H. T., Nguyen, D. (2014). Self Expression versus the Environment: Attitudes in conflict. Young Consumers, 15(2), 138-152. 
The outcome demonstrated a significant number of associations between the variables. To further understand the scope and extent of the associations between the variables, the data were then graphed using the NEP index variable as the dependent variable. Figure 2 illustrates an inverted U shaped curve. Thus, the relationship between the variables is not perfectly linear in nature.

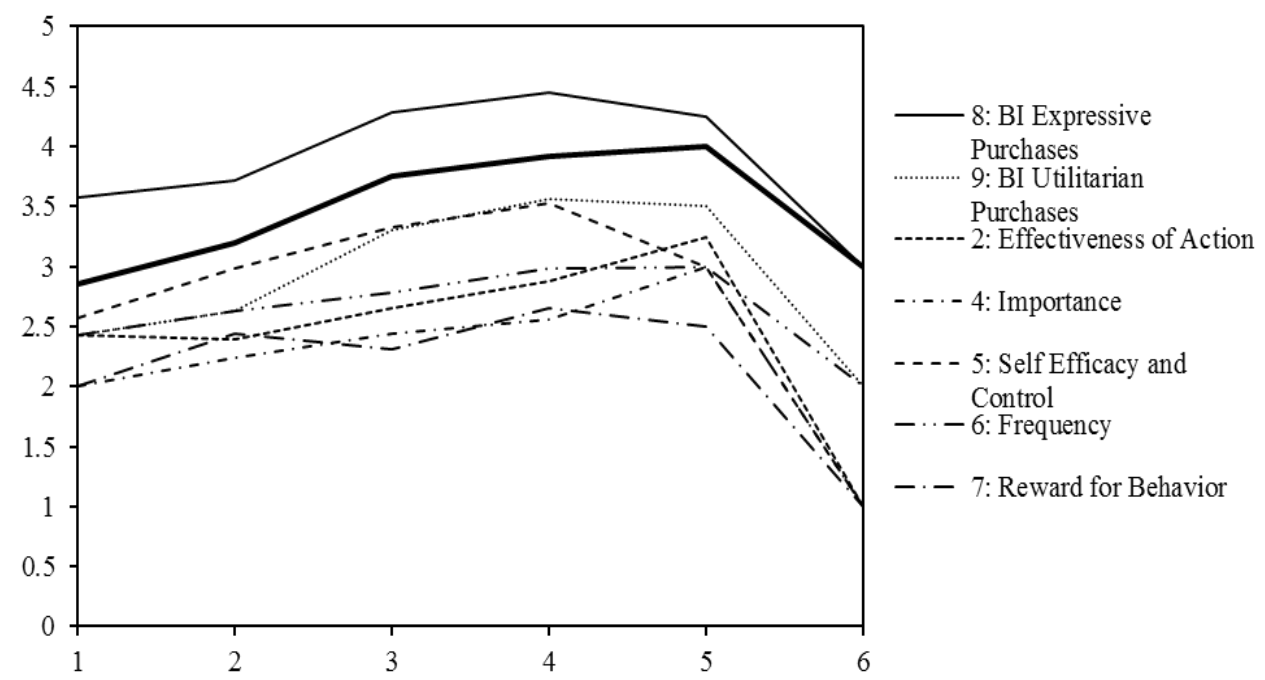

Figure 2. Comparison of means compared with NEP concern for the environment Alpha for all scales was above 0.7. As a result, we combined all scales into single variables by summing the items and averaging the results (De Vellis 2003). The items were then recoded to discrete numbers (for example, $0-1.49=1$ ). The analysis showed that collinearity between the variables was lower than 0.8 and thus it is permissible to run regression analysis. The PLOTS indicated a linear relationship and that the data are relatively homoscedastic. The data are not completely linear and follow a curve (Figure 2).

Notwithstanding the potential curvilinear nature of the data, we ran linear regression on the two variables: expressive and utilitarian purchases. The results are presented in Tables 3 and 4.

This is an author's pre-published copy of the paper Parker, L., Brennan, L., Watne, T. A., Duong, H. T., Nguyen, D. (2014). Self Expression versus the Environment: Attitudes in conflict. Young Consumers, 15(2), 138-152. 
Table 3. Coefficients with Utilitarian Purchases with the Dependent Variable

\begin{tabular}{|c|c|c|c|c|c|c|c|}
\hline & \multicolumn{2}{|c|}{$\begin{array}{c}\text { Unstandardized } \\
\text { Coefficients }\end{array}$} & \multirow{2}{*}{$\begin{array}{c}\text { Standardized } \\
\text { Coefficients } \\
\text { Beta }\end{array}$} & \multirow[b]{2}{*}{$\mathrm{t}$} & \multirow[b]{2}{*}{ Sig. } & \multicolumn{2}{|c|}{$\begin{array}{c}95.0 \% \\
\text { Confidence } \\
\text { Interval for B }\end{array}$} \\
\hline & B & $\begin{array}{l}\text { Std. } \\
\text { Error }\end{array}$ & & & & $\begin{array}{l}\text { Lower } \\
\text { Bound }\end{array}$ & $\begin{array}{l}\text { Upper } \\
\text { Bound }\end{array}$ \\
\hline (constant) & 0.80 & 0.46 & & 1.74 & 0.08 & -0.11 & 1.70 \\
\hline $\begin{array}{l}1 \text { NEP Summated } \\
\text { scale }\end{array}$ & 0.26 & 0.11 & 0.12 & 2.34 & 0.02 & 0.04 & 0.49 \\
\hline $\begin{array}{l}2 \text { Effectiveness of } \\
\text { action }\end{array}$ & 0.00 & 0.11 & 0.00 & 0.00 & 0.99 & -0.21 & 0.21 \\
\hline $\begin{array}{l}3 \text { Family norms } \\
4 \text { Importance of } \\
\text { action for the }\end{array}$ & -0.05 & 0.09 & -0.03 & -0.56 & 0.57 & -0.23 & 0.13 \\
\hline $\begin{array}{l}\text { environment } \\
5 \text { Self efficacy and }\end{array}$ & 0.11 & 0.11 & 0.06 & 0.93 & 0.36 & -0.12 & 0.33 \\
\hline $\begin{array}{l}\text { control } \\
6 \text { Frequency of indv }\end{array}$ & 0.06 & 0.10 & 0.04 & 0.60 & 0.55 & -0.13 & 0.25 \\
\hline $\begin{array}{l}\text { action } \\
7 \text { Reward for }\end{array}$ & 0.39 & 0.08 & 0.27 & 4.71 & 0.00 & 0.23 & 0.55 \\
\hline behaviour & 0.14 & 0.09 & 0.09 & 1.52 & 0.13 & -0.04 & 0.31 \\
\hline
\end{tabular}

Table 4. Coefficients with Expressive Purchases as the Dependent Variable

\begin{tabular}{|c|c|c|c|c|c|c|c|}
\hline & \multicolumn{2}{|c|}{$\begin{array}{l}\text { Unstandardized } \\
\text { Coefficients }\end{array}$} & \multirow{2}{*}{$\begin{array}{c}\text { Standardized } \\
\text { Coefficients } \\
\text { Beta }\end{array}$} & \multirow[b]{2}{*}{$\mathrm{t}$} & \multirow[b]{2}{*}{ Sig. } & \multicolumn{2}{|c|}{$\begin{array}{c}95.0 \% \\
\text { Confidence } \\
\text { Interval for B } \\
\end{array}$} \\
\hline & B & $\begin{array}{l}\text { Std. } \\
\text { Error }\end{array}$ & & & & $\begin{array}{l}\text { Lower } \\
\text { Bound }\end{array}$ & $\begin{array}{l}\text { Upper } \\
\text { Bound }\end{array}$ \\
\hline (constant) & 1.78 & 0.45 & & 3.94 & 0.00 & 0.89 & 2.67 \\
\hline $\begin{array}{l}1 \text { NEP Summated } \\
\text { scale }\end{array}$ & 0.15 & 0.11 & 0.07 & 1.31 & 0.19 & -0.07 & 0.36 \\
\hline $\begin{array}{l}2 \text { Effectiveness of } \\
\text { action }\end{array}$ & -0.14 & 0.10 & $0 .-08$ & -1.36 & 0.17 & -0.35 & 0.06 \\
\hline $\begin{array}{l}3 \text { Family norms } \\
4 \text { Importance of } \\
\text { action for the }\end{array}$ & 0.05 & 0.09 & 0.04 & 0.60 & 0.55 & -0.12 & 0.23 \\
\hline $\begin{array}{l}\text { environment } \\
5 \text { Self efficacy and }\end{array}$ & 0.23 & 0.11 & 0.13 & 2.04 & 0.04 & 0.01 & 0.45 \\
\hline $\begin{array}{l}\text { control } \\
6 \text { Frequency of indv }\end{array}$ & 0.16 & 0.10 & 0.11 & 1.66 & 0.10 & -0.03 & 0.35 \\
\hline $\begin{array}{l}\text { action } \\
7 \text { Reward for }\end{array}$ & 0.35 & 0.08 & 0.25 & 4.34 & 0.00 & 0.19 & 0.51 \\
\hline behaviour & 0.06 & 0.09 & 0.04 & 0.71 & 0.48 & -0.11 & 0.24 \\
\hline
\end{tabular}

This is an author's pre-published copy of the paper Parker, L., Brennan, L., Watne, T. A., Duong, H. T., Nguyen, D. (2014). Self Expression versus the Environment: Attitudes in conflict. Young Consumers, 15(2), 138-152. 
In terms of the original hypotheses, the benchmark variable 'attitudes towards the environment' as measured by the NEP, is positively associated with all the variables but at differing levels. Table 5 summarizes the hypotheses and outcomes of the research.

Table 5. Results of Hypothesis Testing

\begin{tabular}{|c|c|}
\hline Hypothesis & Outcome \\
\hline $\begin{array}{l}\text { H1a: Young adults will adjust their stated } \\
\text { intentions regarding purchases in accordance to } \\
\text { their stated attitudes: positive attitudes towards the } \\
\text { environment will lead to an increase in } \\
\text { consideration for the environment in their purchase } \\
\text { intentions. }\end{array}$ & $\begin{array}{l}\text { Positive correlation between NEP } \\
\text { and purchase behaviours. } \\
\text { Statistically significant at } 0.05 \text { level. } \\
\text { Accepted }\end{array}$ \\
\hline $\begin{array}{l}\text { H1b: Positive attitudes towards the environment } \\
\text { will lead to an increase in consideration for the } \\
\text { environment in the young adults' purchase } \\
\text { intentions in terms of expressive products. }\end{array}$ & $\begin{array}{l}\text { The result was not significant at the } \\
0.05 \text { level. However, a difference at } \\
\text { the } 0.10 \text { level indicating some } \\
\text { support for this hypothesis. } \\
\text { Rejected }\end{array}$ \\
\hline $\begin{array}{l}\text { H1c: Positive attitudes towards the environment } \\
\text { will lead to an increase in consideration for the } \\
\text { environment in the young adults' purchase } \\
\text { intentions in terms of utilitarian products. }\end{array}$ & $\begin{array}{l}\text { Result significant at the } 0.05 \text { level. } \\
\text { Accepted }\end{array}$ \\
\hline $\begin{array}{l}\text { H2a: Young adults' perceived self-efficacy in } \\
\text { relation to their own pro-environmental activities } \\
\text { is not influenced by their attitudes towards the } \\
\text { environment. }\end{array}$ & $\begin{array}{l}\text { Result significant at the } 0.05 \text { level. } \\
\text { Accepted }\end{array}$ \\
\hline $\begin{array}{l}\text { H2b: Young adults' perceived importance of pro- } \\
\text { environmental activities is not influenced by their } \\
\text { attitudes towards the environment. }\end{array}$ & $\begin{array}{l}\text { The result was not significant at the } \\
0.05 \text { level. However, a difference at } \\
\text { the } 0.10 \text { level indicating some } \\
\text { support for this hypothesis. } \\
\text { Rejected }\end{array}$ \\
\hline $\begin{array}{l}\text { H2c: Young adults' sense of personal reward } \\
\text { related to participating in pro-environmental } \\
\text { activities is not influenced by their attitudes } \\
\text { towards the environment. }\end{array}$ & $\begin{array}{l}\text { Result significant at the } 0.05 \text { level. } \\
\text { Accepted }\end{array}$ \\
\hline
\end{tabular}

This is an author's pre-published copy of the paper Parker, L., Brennan, L., Watne, T. A., Duong, H. T., Nguyen, D. (2014). Self Expression versus the Environment: Attitudes in conflict. Young Consumers, 15(2), 138-152. 


\begin{tabular}{l|l}
\hline Hypothesis & Outcome \\
\hline $\begin{array}{l}\text { H2d: Young adults' frequency of participating in } \\
\text { pro-environmental activities is not influenced by } \\
\text { their attitudes towards the environment. }\end{array}$ & Result significant at the 0.05 level. \\
\hline $\begin{array}{l}\text { H2e: Young adults' beliefs about how often their } \\
\text { significant others participate in pro-environmental } \\
\text { behaviours are not influenced by their attitudes } \\
\text { towards the environment. }\end{array}$ & Result significant at the 0.05 level. \\
\end{tabular}

\section{Discussion and conclusion}

Whilst 'greenness' of a product appears to be a moderate consideration for utilitarian purchases, the findings from this study suggests that environmental friendliness is at best low on the list of concerns for this market when deciding on an expressive purchase. For the marketers of environmentally friendly products this represents at least two key challenges: first, to try to shift the attitudes of these upwardly mobile and influential consumers towards thinking of environmental friendliness as an attractive characteristic for potential expressive purchases. Second, making environmentally friendly alternatives of expressive goods more visible and more widely available in Vietnam.

The shift towards environmentally friendly products being considered as desirable has been an emerging trend in other developed countries (Hartmann \& Apaolaza-Ibáñez, 2008; Whitmarsh \& O’Neill, 2010), and including some in Asia (e.g. Lee, 2009). However, this trend has not yet reached Vietnam, and whilst environmental awareness is generally regarded as positive, environmental friendliness is not normally considered during purchase of expressive goods. Perhaps, this attribute may not be seen as a means to gain admiration of others, nor to reinforce one’s own status amongst peers and outsiders. Furthermore, green products may not necessarily equate to luxuriousness in consumers’ minds, or even worse,

This is an author's pre-published copy of the paper Parker, L., Brennan, L., Watne, T. A., Duong, H. T., Nguyen, D. (2014). Self Expression versus the Environment: Attitudes in conflict. Young Consumers, 15(2), 138-152. 
these products may be seen as the reverse: not desirable because they are seen as cheap or rustic alternatives.

Other studies have suggested weak links between clothing purchases and concerns for the environment. Kim \& Damhorst (1998) studied young Americans and found that environmental concerns (NEP) did not clearly relate to environmentally responsible apparel consumption. That finding is in line with the results of this study, although Kim and Damhorst's (1998) data was collected more than a decade ago and a major shift in awareness, attitudes and behaviour has occurred in the meantime. Rhee and Johnson's more recent work indicates that this is an important indicator of 'self' (Rhee \& Johnson, 2012).

Until now environmentally sustainable expressive products are not yet widely available in the Vietnamese market, nor are they widely promoted or visible.

Whether certain reported behaviours were caused by certain attitudes cannot be positively determined since the data in this study are correlational and not experimental nor longitudinal. Furthermore, the non-linear nature of the results provides potential to explore the relationships between variables in an entirely different manner to that previously applied to the problem.

While the inverted-U-shaped curve presented a somewhat surprising result, the curve also presents implications for possible underlying (non linear) factors, as yet unexplored. The inverted-U curve has been used in environmental economics (List \& Gallet, 1999; Harbaugh, Levinson, \& Wilson, 2002), marketing and advertising (Nordhielm, 2002; Halkias \& Kokkinaki, 2011), and has a long history in consumer psychology (cf. Yerkes \& Dodson, 1908; Teigen, 1994). In this context, however, the results are 'new news' and provide a rich source of potential for developing strategies based on income, information sources used and the types of consumption patterns adopted by young people when considering self-expressive purchases. Purveyors of green products and ideas, such as governments seeking to protect the

This is an author's pre-published copy of the paper Parker, L., Brennan, L., Watne, T. A., Duong, H. T., Nguyen, D. (2014). Self Expression versus the Environment: Attitudes in conflict. Young Consumers, 15(2), 138-152. 
environment might find social marketing to be necessary to increase the desirability of proenvironmental products choices. However, there is an optimal level of response to environmental threats as Figure 2 shows. It would appear that the reward for social status associated with expressive products sufficiently outweighs concern for the environment and related threat perceptions.

Furthermore, our data show that family norms are the second most important factor influencing intention to purchase environmentally friendly products. This again, provides a social context for decision making that is unusual in adolescents, certainly in Western cultures. While this may be an artifact of collectivism, it is worthy of consideration in future studies. How these family dynamics play out will be important to explore.

This research illustrates that the current sample of Vietnamese consumers, both upwardly mobile and young, do not consider the environment important with regards to expressive purchases decisions. Nevertheless, they do consider the environment important and, relating to more utilitarian types of purchases, they indicate environmental concern at a higher level. However, as these upwardly mobile young adults are increasingly able to buy and consume material goods, this dichotomy is problematic for those concerned with environmental issues. In order to establish pro-environmentalism as a worthwhile and appropriately status-filled activity within a context such as this, marketers will perhaps need to change the position green products have in the mind of these consumers.

This is an author's pre-published copy of the paper Parker, L., Brennan, L., Watne, T. A., Duong, H. T., Nguyen, D. (2014). Self Expression versus the Environment: Attitudes in conflict. Young Consumers, 15(2), 138-152. 


\section{Reference list}

Ajzen, I. (1991), “The theory of planned behavior”, Organizational Behavior and Human Decision Processes, Vol. 50 No. 2, pp.179-211.

Ajzen, I., \& Fishbein, M. (1980), Understanding attitudes and predicting social behavior. Englewood Cliffs, NJ, USA: Prentice-Hall.

Amburgey, J. W., \& Thoman, D. B. (2012), “Dimensionality of the New Ecological Paradigm: Issues of factor structure and measurement” Environment and Behavior. Vol. 44 No. 2, pp. 235-256.

Bardhan, P. (2006), “Crouching Tiger, Lumbering Elephant-The rise of China and India in a comparative economic perspective”, Brown Journal of World Affairs, Vol. 13 No. 1, pp. 49-62.

Blodgett, J. G., Bakir, A., \& Rose, G. M. (2008), “A test of the validity of Hofstede's cultural framework”, Journal of Consumer Marketing, Vol. 25 No. 6, pp. 339-349.

Bonnes, M., Passafaro, P., \& Carrus, G. (2011), “The Ambivalence of Attitudes toward urban green areas: Between proenvironmental worldviews and daily residential experience”, Environment and Behavior, Vol. 43 No. 2, pp. 207-232.

Cheng, J. C. H., \& Monroe, M. C. (2012), “Connection to Nature” Environment and Behavior, Vol. 44 No. 1, pp. 31-49.

Chung, S-S., \& Poon, C-S. (1999), “The attitudes of Guangzhou citizens on waste reduction and environmental issues”, Resources, Conservation and Recycling, Vol. 25 No. 1, pp. 35-59.

Chung, S-S., \& Poon, C-S. (2001), “A comparison of waste-reduction practices and new environmental paradigm of rural and urban Chinese citizens”, Journal of Environmental Management, Vol. 62 No. 1, pp. 3-19.

This is an author's pre-published copy of the paper Parker, L., Brennan, L., Watne, T. A., Duong, H. T., Nguyen, D. (2014). Self Expression versus the Environment: Attitudes in conflict. Young Consumers, 15(2), 138-152. 
Churchill, G. A., \& Iacobucci, D. (2005), Marketing research: methodological foundations (9 ed.). Mason, Ohio: Thomson South-Western.

Cialdini, R. B., Reno, R. R., \& Kallgren, C. A. (1990), “A focus theory of normative conduct: recycling the concept of norms to reduce littering in public places”, Journal of Personality and Social Psychologist, Vol. 58 No. 6, pp. 1015-1036.

Cin, C. K. (2012), "Blaming the Government for Environmental Problems: A Multilevel and Cross-National Analysis of the Relationship Between Trust in Government and Local and Global Environmental Concerns”, Environment and Behavior DOI:10.1177/0013916512453840

Cini, F., Leone, L., \& Passafaro, P. (2012), “Promoting Ecotourism Among Young People” Environment and Behavior, Vol. 44 No.1, pp. 87-106.

Cleveland, M., Kalamas, M., \& Laroche, M. (2012), “““It's not Easy Being Green”: Exploring Green Creeds, Green Deeds, and Internal Environmental Locus of Control”, Psychology and Marketing, Vol. 29 No. 5, pp. 293-305.

Cordano, M., Welcomer, S., Scherer, R. F., Pradenas, L., \& Parada, V. (2011), “A crosscultural assessment of three theories of pro-environmental behavior”, Environment and Behavior, Vol. 43 No. 5, pp. 634-657.

Corral-Verdugo, V., Carrus, G., Bonnes, M., Moser, G., \& Sinha, B. P. (2008), “Environmental beliefs and endorsement of sustainable development principles in water conservation: Toward a new human interdependence paradigm”, Environment and Behavior, Vol. 40 No. 5, pp.703-725.

Cronbach, L. J. (1951), “Coefficient alpha and the internal structure of tests”, Psychometrika, Vol. 16 No. 3, pp. 297-334.

This is an author's pre-published copy of the paper Parker, L., Brennan, L., Watne, T. A., Duong, H. T., Nguyen, D. (2014). Self Expression versus the Environment: Attitudes in conflict. Young Consumers, 15(2), 138-152. 
de Mooij, M., \& Hofstede, G. (2002), “Convergence and divergence in consumer behavior: implications for international retailing”, Journal of Retailing, Vol. 78 No. 1, pp. 6169.

De Vellis, R. F. (2003), Scale Development: Theory and Applications (2nd ed.). Thousand Oaks, CA: Sage Publications.

Deng, J., Walker, G. J., \& Swinnerton, G. (2006), “A comparison of environmental values and attitudes between Chinese in Canada and Anglo-Canadians”, Environment and Behavior, Vol. 38 No. 1, pp. 22-47.

Donovan, R., \& Henley, N. (2003), Social Marketing Principles and Practice. East Hawthorn Victoria Australia: IP Communications.

Dung, T. (2011), “Craft villages cause environment pollution”, The Saigon Times. Retrieved from: http://english.thesaigontimes.vn/Home/business/environment/19401/. Access date: 18 Jul 2011.

Dunlap, R. E., \& Van Liere, K. D. (1978), “The 'New Environmental Paradigm' A proposed measuring instrument and preliminary results”, The Journal of Environmental Education, Vol. 9 No. 4, pp. 10-19.

Dunlap, R. E., Van Liere, K. D., Mertig, A. G., \& Jones, R. E. (2000), “Measuring endorsement of the New Ecological Paradigm: A revised NEP scale”, Journal of Social Issues, Vol. 56 No. 3, pp. 425-442.

Floyd, D. L., Prentice-Dunn, S., \& Rogers, R. W. (2000), “A meta-analysis of research on protection motivation theory”, J Appl Soc Psychol, Vol. 30, pp. 407-429.

Fritsche, I., \& Hafner, K. (2011), “The malicious effects of existential threat on motivation to protect the natural environment and the role of environmental identity as a moderator”, Environment and Behavior, Vol. 44 No. 4, pp. 570-590.

This is an author's pre-published copy of the paper Parker, L., Brennan, L., Watne, T. A., Duong, H. T., Nguyen, D. (2014). Self Expression versus the Environment: Attitudes in conflict. Young Consumers, 15(2), 138-152. 
General Statistics Office. (2009). The 2009 Vietnam Population and Housing Census: Major Findings. Ha Noi, Vietnam: Ban Chỉ Đạo Tổng Điều Tra Dân Số và Nhà ở Trung Ương, Tổng Cục Thống Kê (Central Population and Housing Census Steering Committee, General Statistics Office).

Halkias, G., \& Kokkinaki, F. (2011), “Increasing advertising effectiveness through incongruity-based tactics: The moderating role of consumer involvement”, Journal of Marketing Communications, Vol. 19 No. 3, pp. 182-197.

Hallin, P. O. (1995), “Environmental Concern and Environmental Behavior in Foley, a Small Town in Minnesota”, Environment and Behavior, Vol. 27 No. 4, pp. 558-578.

Hanser, A. (2010), “Uncertainty and the problem of value: Consumers, culture and inequality in urban China”, Journal of Consumer Culture, Vol. 10 No. 3, pp. 307-332.

Harbaugh, W. T., Levinson, A., \& Wilson, D. M. (2002), "Reexamining the empirical evidence for an environmental Kuznets curve”, Review of Economics and Statistics, Vol. 84 No. 3, pp. 541-551.

Hartmann, P., \& Apaolaza-Ibáñez, V. (2008), “Virtual nature experiences as emotional benefits in green product consumption”, Environment and Behavior, Vol. 40 No. 6, pp. 818-842.

Hawcroft, L. J., \& Milfont, T. (2010), “The use (and abuse) of the new environmental paradigm scale over the last 30 years: A meta-analysis”, Journal of Environmental Psychology, Vol. 30 No. 2, pp. 43-148.

Hoang Loc, \& Duc Tuyen. (2012, 21 August 2012), Xả thẳng nước thải ra kênh. Tuoi tre Newspapers http://thethao.tuoitre.vn/The-thao/502464/Xa-thang-nuoc-thai-rakenh.html

This is an author's pre-published copy of the paper Parker, L., Brennan, L., Watne, T. A., Duong, H. T., Nguyen, D. (2014). Self Expression versus the Environment: Attitudes in conflict. Young Consumers, 15(2), 138-152. 
Holt, D. B. (2004), How brands become icons: The principles of cultural branding: Boston, MA, USA: Harvard Business Press.

Homburg, A., \& Stolberg, A. (2006), “Explaining pro-environmental behavior with a cognitive theory of stress”, Journal of Environmental Psychology, Vol. 26 No.1, pp. $1-14$.

Hughes, H., \& Woldekidan, B. (1994), “The emergence of the middle class in ASEAN countries”, ASEAN Economic Bulletin, Vol. 11 No. 2, pp. 139-149.

Johnson, C. Y., Bowker, J. M., \& Cordell, H. K. (2004), “Ethnic variation in environmental belief and behavior”, Environment and Behavior, Vol. 36 No. 2, pp. 157-186.

Kahneman, D., \& Tversky, A. (1984), “Choices, Values, and Frames”, American Psychologist, Vol. 21 No. 4, pp. 341-350.

Kallgren, C. A., Reno, R. R., \& Cialdini, R. B. (2000), “A focus theory of normative conduct: When norms do and do not affect behavior”, Personality \& Social Psychology Bulletin, Vol. 26 No. 8, pp. 1002-1012.

Keegan, W. J., \& Green, M. (2010), Global Marketing: Global Edition (6 ed.). New Jersey: Pearson Higher Education.

Kim, H.-S., \& Damhorst, M. L. (1998), “Environmental concern and apparel consumption”, Clothing and Textiles Research Journal, Vol. 16 No. 3, pp. 126-133.

Kim, Y. (2011). The Social Foundation of Luxury Good Obsession in South Korea. Unpublished Master's Thesis, The Faculty of the Graduate School of Arts and Sciences, Global Studies, Brandeis University

Kurz, T., \& Baudains, C. (2012), “Biodiversity in the Front Yard An Investigation of Landscape Preference in a Domestic Urban Context”, Environment and Behavior, Vol. 44 No. 2, pp. 166-196.

This is an author's pre-published copy of the paper Parker, L., Brennan, L., Watne, T. A., Duong, H. T., Nguyen, D. (2014). Self Expression versus the Environment: Attitudes in conflict. Young Consumers, 15(2), 138-152. 
Lapinski, M. K., \& Rimal, R., N. (2005), “An explication of social norms”, Communication Theory, Vol. 15 No 2, pp. 127-147.

Lee, K. (2009), “Gender differences in Hong Kong adolescent consumers' green purchasing behavior”, Journal of Consumer Marketing, Vol. 26 No. 2, pp. 87-96.

Lee, J. Y., Halter, H., Johnson, K. K., \& Ju, H. (2013), “Investigating fashion disposition with young consumers”, Young Consumers: Insight and Ideas for Responsible Marketers, Vol. 14 No. 1, pp. 67-78.

List, J. A., \& Gallet, C. A. (1999), “The Kuznets Curve: what happens after the inverted U?” Review of Development Economics, Vol. 3 No. 2, pp. 200-206

Maslow, A. H. (1943), “A theory of human motivation”, Psychological Review, Vol. 50 No. 4, pp. 370-396.

Munro, S., Lewin, S., Swart, T., \& Volmink, J. (2007), “A review of health behaviour theories: how useful are these for developing interventions to promote long-term medication adherence for TB and HIV/AIDS?”, BMC Public Health, Vol. 7 No. 1, pp. 104 DOI doi:10.1186/1471-2458-7-104

Mynatt, C., \& Sherman, S. J. (1975), "Responsibility attribution in groups and individuals: A direct test of the diffusion of responsibility hypothesis”, Journal of Personality and Social Psychology, Vol. 32 No. 6, pp. 1111-1118.

Nayeem, T. (2011), A comparative study of Individualist and Collectivist consumer's decision making styles in high involvement purchase situations: A case of automobile purchase. Unpublished Doctoral Thesis, Faculty of Business and Enterprise, Swinburne University of Technology, Hawthorn Victoria Australia.

Ngai, J., \& Cho, E. (2012), “The young luxury consumers in China”, Young Consumers: Insight and Ideas for Responsible Marketers, Vol. 13 No. 3, pp. 255-266

This is an author's pre-published copy of the paper Parker, L., Brennan, L., Watne, T. A., Duong, H. T., Nguyen, D. (2014). Self Expression versus the Environment: Attitudes in conflict. Young Consumers, 15(2), 138-152. 
Nguyen, T. B. M., \& Amin, A. T. M. N. (2002), “The role of foreign direct investment in urban environmental management: Some evidence from Hanoi, Vietnam”, Environment, Development and Sustainability, Vol. 4 No. 3, pp. 279-297.

Nisbet, E. K., Zelenski, J. M., \& Murphy, S. A. (2009), “The Nature Relatedness Scale”, Environment and Behavior, Vol. 41 No. 5, pp. 715-740.

Nooney, J. G., Woodrum, E., Hoban, T. J., \& Clifford, W. B. (2003), “Environmental Worldview and behavior”, Environment and Behavior, Vol. 35 No. 6, pp. 763-783.

Nordhielm, C. L. (2002), "The influence of level of processing on advertising repetition effects”, Journal of Consumer Research, Vol. 29 No. 3, pp. 371-382.

Nordlund, A. M., \& Garvill, J. (2002), “Value Structures behind Proenvironmental Behavior”, Environment and Behavior, Vol. 34 No. 6, pp. 740-756.

Ogden, D. T., Ogden, J. R., \& Schau, H. J. (2004), “Exploring the impact of culture and acculturation on consumer purchase decisions: Toward a microcultural perspective”, Academy of Marketing Science Review, Vol. 3, pp. 1-22 Available on line at: http://www.amsreview.org/articles/ogden03-2004.pdf

Osbaldiston, R., \& Sheldon, K. M. (2003), "Promoting internalized motivation for environmentally responsible behavior: A prospective study of environmental goals”, Journal of Environmental Psychology, Vol. 23 No. 4, pp. 349-357.

Penz, E., \& Kirchler, E. (2012), “Sex-Role Specialization in a Transforming Market: Empirical Evidence from Vietnamese Middle-Class Households”, Journal of Macromarketing, Vol. 32 No. 1, pp. 61-73.

Perera, L. C. R., \& Hewege, C. R. (2013), “Climate change risk perceptions and environmentally conscious behaviour among young environmentalists in Australia”, Young Consumers: Insight and Ideas for Responsible Marketers, Vol. 14 No. 2, pp. 139-154.

Rhee, J., \& Johnson, K. K. (2012), “Investigating relationships between adolescents' liking for an

This is an author's pre-published copy of the paper Parker, L., Brennan, L., Watne, T. A., Duong, H. T., Nguyen, D. (2014). Self Expression versus the Environment: Attitudes in conflict. Young Consumers, 15(2), 138-152. 
apparel brand and brand self congruency”, Young Consumers: Insight and Ideas for Responsible Marketers, Vol. 13 No. 1, pp. 74-85.

Roberts, J. A., \& Bacon, D. R. (1997), “Exploring the Subtle Relationships between

Environmental Concern and Ecologically Conscious Consumer Behavior”, Journal of Business Research, Vol. 40 No. 1, pp. 79-89.

Roll, M. (2006), Asian brand strategy: how Asia builds strong brands. New York: Palgrave Macmillan.

Rosentrater, L. D., Sælensminde, I., Ekström, F., Böhm, G., Bostrom, A., Hanss, D., et al. (2012), “Efficacy Trade-Offs in Individuals’ Support for Climate Change Policies”, Environment and Behavior. doi 10.1177/0013916512450510

Sax, L. J., Gilmartin, S. K., Lee, J. J., \& Hagedorn, L. S. (2008), “Using web surveys to reach community college students: an analysis of response rates and response bias”, Community College Journal of Research and Practice, Vol. 32 No. 9, pp. 712-729.

Schroeder, J. (2011), “Back to basics: Redefining the biotechnology message”, Industrial Biotechnology, Vol. 7 No. 3, pp.192-193.

Schultz, P. W., Gouveia, V. V., Cameron, L. D., Tankha, G., Schmuck, P., \& Franek, M. (2005), "Values and their relationship to environmental concern and conservation behavior”, Journal of Cross-Cultural Psychology, Vol. 36 No. 4, pp. 457-475.

Schultz, W. C., Nolan, J. M., Cialdini, R. B., Goldstein, N. J., \& Griskevicius, V. (2007), "The constructive, destructive and reconstructive power of social norms", Psychological Science, Vol. 18 No. 5, pp. 429-434.

Schütte, H., \& Ciarlante, D. (1998), Consumer behavior in Asia. New York: New York University Press.

This is an author's pre-published copy of the paper Parker, L., Brennan, L., Watne, T. A., Duong, H. T., Nguyen, D. (2014). Self Expression versus the Environment: Attitudes in conflict. Young Consumers, 15(2), 138-152. 
Schwartz, S. H. (1992), “Universals in the content and structure of values: Theoretical advances and empirical tests in 20 countries”, Advances in Experimental Social Psychology, Vol. 25, pp. 1-65.

Schwartz, S. H., Melech, G., Lehmann, A., Burgess, S., Harris, M., \& Owens, V. (2001), "Extending the cross-cultural validity of the theory of basic human values with a different method of measurement”, Journal of Cross-Cultural Psychology, Vol. 32 No. 5, pp. 519-542.

Sheth, J. N. (2011), “Impact of emerging markets on marketing: rethinking existing perspectives and practices”, Journal of Marketing, Vol. 75 No 4, pp. 166-182.

Sheth, J. N., Sethia, N. K., \& Srinivas, S. (2011), “Mindful consumption: a customer-centric approach to sustainability”, Journal of the Academy of Marketing Science, Vol. 39 No. 1, pp. 21-39.

Singh, N. (2005), “The idea of South Asia and the role of the middle class”, University of California SCCIE Working Paper No. 05-08.

Soares, A. M., Farhangmehr, M., \& Shoham, A. (2007), "Hofstede's dimensions of culture in international marketing studies”, Journal of Business Research, Vol. 60 No. 3, pp. 277-284.

Stern, P. C. (2000), “New Environmental Issues: Toward a coherent theory of environmentally significant behavior”, Journal of Social Issues, Vol. 56 No. 3, pp. 407-424.

Stern, P. C., Dietz, T., \& Kalof, L. (1993), “Value orientations, gender and environmental concern”, Environment and Behavior, Vol. 25 No. 3, pp. 322-348.

Teigen, K. H. (1994), “Yerkes-Dodson: A law for all seasons”, Theory \& Psychology, Vol. 4 No. 4, pp. 525-547.

This is an author's pre-published copy of the paper Parker, L., Brennan, L., Watne, T. A., Duong, H. T., Nguyen, D. (2014). Self Expression versus the Environment: Attitudes in conflict. Young Consumers, 15(2), 138-152. 
Thanh Niên. (2011). Residents clash with polluters. Thanh Niên, Retrieved from:

http://www.thanhniennews.com/2010/Pages/20110903171113.aspx. Access date: 21

Oct 2011.

Thogersen, J. (2006), “Norms for environmentally responsible behaviour: An extended taxonomy”, Journal of Environmental Psychology, Vol. 26 No. 4, pp. 247-261.

Thogersen, J., \& Ölander, F. (2003), “Spillover of environment-friendly consumer behavior”, Journal of Environmental Psychology, Vol. 23 No. 3, pp. 225-236.

Thu Hang. (2012, 10 August 2012). Công ty Dệt 19-5 xả thải hủy diệt môi trường. Ha Noi Moi Newspapers http://hanoimoi.com.vn/newsdetail/Moi-truong/555918/cong-ty-det195-xa-thai-huy-diet-moi-truong.htm

Tversky, A., \& Kahneman, D. (1981), “The Framing of Decisions and the Psychology of Choice”, Science, Vol. 211, pp. 453-458.

VietNamNet. (2009). In HCM City, traffic jams have become a way of life. VietNamNet, Retrieved from: http://english.vietnamnet.vn/reports/2009/07/856640/. Access date: 18 Jul 2011.

Vikan, A., Camino, C., Biaggio, A., \& Nordvik, H. (2007), "Endorsement of the New Ecological Paradigm”, Environment and Behavior, Vol. 39 No. 2, pp. 217-228. Wallach, M. A., Kogan, N., \& Bem, D. J. (1964), “Diffusion of responsibility and level of risk taking in groups”, The Journal of Abnormal and Social Psychology, Vol. 68 No. 3, pp. 263-274.

Watne, T., \& Brennan, L. (2011), “Behavioral change starts in the family: The role of family communication and implications for social marketing”, Journal of Nonprofit \& Public Sector Marketing, Vol. 23 No. 4, pp. 367-386.

This is an author's pre-published copy of the paper Parker, L., Brennan, L., Watne, T. A., Duong, H. T., Nguyen, D. (2014). Self Expression versus the Environment: Attitudes in conflict. Young Consumers, 15(2), 138-152. 
Watson, K., \& Halse, C. M. (2005), “Environmental attitudes of pre-service teachers: A conceptual and methodological dilemma in cross-cultural data collection”, Asia Pacific Education Review, Vol. 6 No. 1, pp. 59-71.

Whitmarsh, L., \& O'Neill, S. (2010), “Green identity, green living? The role of proenvironmental self-identity in determining consistency across diverse proenvironmental behaviours”, Journal of Environmental Psychology, Vol. 30 No. 3, pp. 305-314.

Widegren, O. (1998), “The New Environmental Paradigm and personal norms”, Environment and Behavior, Vol. 30 No. 1, pp. 75-100.

Xiao, C. (2013), "Public Attitudes Toward Science and Technology and Concern for the Environment: Testing a Model of Indirect Feedback Effects”, Environment and Behavior. Vol. 45 No. 1 pp. 113-137

Yerkes, R. M., \& Dodson, J. D. (1908), “The relation of strength of stimulus to rapidity of habit formation”, Journal of Comparative Neurology and Psychology, Vol. 18 No. 5, pp. 459-482.

Zavestoski, S. (2002), “The social-psychological bases of anticonsumption attitudes”, Psychology \& Marketing, Vol 19 No. 2, pp. 149-165.

This is an author's pre-published copy of the paper Parker, L., Brennan, L., Watne, T. A., Duong, H. T., Nguyen, D. (2014). Self Expression versus the Environment: Attitudes in conflict. Young Consumers, 15(2), 138-152. 